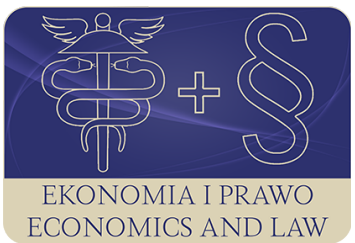

EKONOMIA I PRAWO. ECONOMICS AND LAW

Volume 20, Issue 1, March 2021

p-ISSN 1898-2255, e-ISSN 2392-1625

www.economicsandlaw.pl

ORIGINAL ARTICLE

received 02.11.2019; revised 18.01.2021; accepted 31.03.2021

Citation: Bochenek, M. (2021). Views of Joseph E. Stiglitz on the role and scope of the state's

influence on the economy against the background of previous views. Ekonomia i Prawo. Economics and Law, 20(1): 5-19. doi:10.12775/EiP.2021.001.

\title{
Views of Joseph E. Stiglitz on the role and scope of the state's influence on the economy against the background of previous views
}

\author{
MIROSEAW BOCHENEK \\ Nicolaus Copernicus University in Torun, Faculty of Economic Sciences and Management, \\ Department of Economics, ul. Gagarina 13A, 87-100 Toruń, Poland \\ ๑ bochenek@umk.pl \\ orcid.org/0000-0002-5914-2789
}

\begin{abstract}
Motivation: In the history of economic thought up to now, one of the topics causing the fiercest disputes was the role of the state and the market in economic life. The creators of the oldest concepts suggested that the state should steer the economy. Since the beginning of the $18^{\text {th }}$ century, the supporters of laissez-faire, the invisible hand of the market, and the auctioneer have been getting more and more respect. Their creators argued that the free market works efficiently and effectively. These views were undermined by the Great Depression. In response to the deep recession, Keynesianism was created, which led to the radicalization of supporters of a strong state on the one hand, and an unhampered market on the other.
\end{abstract}

Aim: The aim of this article is to present in a synthetic way the evolution of views on the resource allocation mechanism in the economy. The research problem can be contained in three questions: How have theoretical views on the role of the state and the market in the economy evolved? Which views remain relevant? What is Joseph E. Stiglitz's contribution to the discussion on the state-market relationship?

Result: An innovative solution was proposed by Joseph E. Stiglitz. He pointed out that the state and the market should not be opposed as mechanisms for coordinating economic activity. He was in favour of developing ways of cooperation between the state and the market in order to ensure the effective functioning of modern economies that 
are mixed economies. This solution has rendered out of date the existing dispute between supporters of interventionism and laissez-faire.

Keywords: history of economic thought; the role of the market in the economy; the role of the state in the economy; liberalism; interventionism

JEL: B11; B12; B13; B14; B15; B20; H11

\section{Introduction}

For two thousand four hundred years, philosophers, social thinkers and economists have wondered which economic process regulator fulfils its functions better: the market or the state. During that period, many views were expressed and the topic continues to attract the attention of successive generations of economists. What is more, this issue is one of the most exciting and stimulates lively economic disputes. Original, and in many cases mutually exclusive, concepts on this subject have been formulated by, among others: Plato, St Thomas More, B. Mandeville, V.J.C.M. de Gournay, R. Cantillon, F. Quesnay, A. Smith, F. Lassalle, J.G. Fichte, A.H.G. Wagner, L.M.E. Walras, and J.M. Keynes.

At the end of the $20^{\text {th }}$ century and at the beginning of the $21^{\text {st }}$, J.E.Stiglitz presented an innovative view on the mechanism of economic activity coordination. Stiglitz, awarded the Nobel Prize in Economic Sciences in 2001, dealt with the public sector and was involved in many countries as a government adviser, and at the same time participated in discussions on the economic analysis of the public economy.

The aim of this study is to present - owing to its constraints the most important views that arose from the $4^{\text {th }}$ century $\mathrm{BC}$ to the beginning of the $21^{\text {st }}$ century on the roles of the state and of the market in the economy, and to indicate the originality of Joseph E. Stiglitz's thoughts on the resource allocation mechanism. The research problem of the article is encapsulated in the following questions: How have theoretical views on the role of the state and the market in the economy evolved? Which views remain relevant? What is Joseph E. Stiglitz's contribution to the discussion on the desirable state-market relationship?

In order to achieve the above aims and research tasks, the author of the article reviewed the professional literature and made a selection from it, and also applied the method of deduction and the method of critical analysis of the literature on the subject. The considerations carried out are of a normative character. The presented views and assessments relate to the proposed solutions in the field of macroeconomics. In earlier studies on this subject, their authors were either in favour of a strong and active state, i.e. statism or interventionism, or they were in favour of the unrestricted operation of the market, i.e. liberalism, or confronted the above-mentioned trends (among others: Dach, 2008; Jarmołowicz, 2012; Owsiak, 2017). On the other hand, in this study the author has compiled what constitutes its novum - three positions, and has shown that there are not only two mutually exclusive views on the mechanism of the coor- 
dination of the activities of economic entities, but also that the proposal of J.E. Stiglitz has rendered out of date the dispute between the two orthodox currents.

\section{The first supporters of a strong state}

The authors of the first views on the mechanism of economic activity coordination argued for a strong state that should interfere with economic life. Plato was the first thinker to deal with the regulator of economic processes. In his extensive work entitled The republic, dated to 381 BC, the Greek philosopher presented the first model of the ideal state in the history of mankind. According to Plato (1992, pp. 34 et seq.), the state was expected to be omnipotent and at the same time obliged to form good citizens. State interference was to cover all areas of social life, including the economy. The author of The republic assumed state totalism. The economy was to be subordinated to the central plan. There was no room for the market in this model. The goal of this state was not to increase the welfare of the whole society, not to increase production, and not the issue of a fair distribution of social income, but an ideal goal - the achievement of excellence by citizens.

Almost one thousand and nine hundred years later, a similar vision of a society without a market was presented by St Thomas More (1964, pp. 9 et seq.). In the book from 1516 entitled Utopia, an English statesman and humanist outlined a vision of an ideal classless society, a well-organized state in which he rejected monetary economy and private property. The organization of the state was to include the equality of all citizens, the collective organization of production, and the universal obligation of six hours of work a day. The products manufactured in craft workshops were to be divided according to needs and serve the whole of society. The entire autarkic economy was subject to authoritative planning.

The above means that Plato and St. Thomas More outlined utopian visions of the functioning of society without the market and money, while the real economy developed spontaneously towards a commodity-money economy.

In mercantile thought, which dominated from the end of the fifteenth to the mid-eighteenth century, the market was not eliminated, but the state played the role of the main economic decision maker. The state protected domestic production against foreign competition, supported the development of the factory industry, and manufactures focused on export and anti-import production, as well as the development of merchant shipping, navy, and port construction, granting subsidies and special monopoly rights to trade in colonial markets. In addition, the state supported population growth in order to increase labour supply, reduce wages, and increase competitiveness in foreign markets. Mercantilism, therefore, recommended the industrialization of the country, that is, the industrialization and creation of an autarkic economy. For the first time in Europe the authors of this doctrine introduced protectionism, which is a deliberate tool of economic policy. Thus, the protectionist policy accepted 
state intervention in the economy. The advocates of an active and strong state were, among others: Josiah Child (1751, pp. V et seq.), John Hales (1958, pp. 5 et seq.), Edward Misselden (1622, pp. 7 et seq.; 1623, pp. 1-145), Antoine de Montchrétien (1970, pp. 1 et seq.), Thomas Mun (1856, pp. 1-47), William Petty (1899a, pp. 5 et seq.; 1899b, pp. 249 et seq.; 1899c, pp. 103 et seq.), and Antonio Serra (1958, pp. 105-130). The countries that implemented the mercantile recommendations entered the path of economic development the fastest. But over time, these desiderata became a barrier to further development, providing arguments to the opponents of state interference in the economy.

\section{Supporters of liberalism}

Bernard Mandeville (1988, p. 197), who formulated the outline of the concept of the invisible hand of the market, made a radical change in the perception of the market's role in the economy, although he did not use the concept. In his book The fable of the bees, published in 1714, he noticed that the market itself regulates the volume of employment in individual branches, and thus the production, providing balance. He put this thought in the following way: 'As it is Folly to set up Trades that are not wanted, so what is next to it is to increase in any one Trade the Numbers beyond what are required. As Things are managed with us, it would be preposterous to have as many Brewers as there are Bakers, or as many Woollen-drapers as there are Shoemakers. This Proportion as to Numbers in every Trade finds itself, and is never better kept than when nobody meddles or interferes with it'.

In the middle of the $18^{\text {th }}$ century ${ }^{1}$ Bernard Jean Claude Marie de Gournay proposed the postulate of non-intervention of the state power in economic activities. This French marquis merchant, financier, and high state official introduced the principle of economic freedom, that is, the famous slogan of laissez-faire, which reads: laissez faire, laissez passer. It signifies the freedom to conduct trade and industry, or the postulate of not disturbing, in order for things to go their own way, that is, allow free activity (Turgot, 1844, pp. 262-291; Zagórski, 1963, pp. 175-176, 185).

Richard Cantillon (1979, pp. 3 et seq.), an Irish-English banker and merchant, was the author of the first systematic treaty in the field of political economy. In 1725, he wrote a book entitled Essai sur la nature du commerce en général, which was published after his death only in 1755 . He pointed out in it that in every economy, the number of individual entrepreneurs and professions, which ensures equilibrium on all markets, is self-determined. A surplus of producers leads to bankruptcy, while scarcity encourages the creation of new entities. At the same time, he accepted the possibility of the state's influence in the economy, although he emphasized its limits.

1 Since the VJCM de Gournay has not left any writings, the precise date of formulation of this thought is unknown. It is known that he lived in the years 1712-1759. 
François Quesnay (1928, pp. 79-94), creator of physiocracy, was also an advocate of unfettered economic freedom. In the work Natural law, published in 1765 , he stated that it is the natural right of every human being to run a business for his or her own benefit. Economic activity requires the guaranteeing of the freedom of production, trade, and consumption. The task of guaranteeing the freedom of every person and of his property rests with the state. Private property, however, should pursue the general goals of the state, otherwise the government may modify its activities and supervise the activities of individual members. But the more the government limits its power, the more freedom the citizens get. The free activity of individuals is in line with natural development and ensures development and wealth higher than in the conditions of government intervention in socio-economic life. Each individual is able to choose the most favourable activity for himself, which is also the most appropriate from the point of view of the state, leading to its well-being (Zagórski, 1963, pp. 39-51).

In his book An inquiry into the nature and causes of the wealth of nations (1776), Adam Smith made recommendations to politicians to provide wealth to the public. He showed that it is a market mechanism called the 'invisible hand' of the market that alone sets the prices of goods and services, the volume of their production, and the income of the factors of production, ensuring balance in individual branches and in the entire economy. He presented the idea of the 'invisible hand', understood as a force coordinating the actions of people, for the first time in 1759 in The theory of moral sentiments (Smith, 2004, p. 215), and developed in An inquiry into the nature and causes of the wealth of nations (Smith, 1863, p. 199). The free market enables the most efficient meeting of consumers' needs. His political and economic programme was a programme of economic liberalism. The state should create favourable conditions for conducting the business activity of individuals, lift all restrictions, and not restrict their activity. While minimizing its functions, the state should limit itself to setting denominations of banknotes, setting interest rates, conducting general education, running mail, justice, national defence, conducting public works, and implementing large projects. Therefore, according to A. Smith (1863, pp. 221-248, 311-411), a laissez-faire economic policy of the government is in the interests of the whole of society.

A. Smith's political and economic views were accepted and justified by his supporters, among others: Thomas Robert Malthus, Jean Baptiste Say, David Ricardo, and John Stuart Mill.

In the following decades, the liberal views of the classics on the beneficial effects of the unhampered market mechanism for the economy and society were accepted and developed by academic economists. One of them was Léon Marie Esprit Walras (1926, pp. 122 et seq.), who, in 1874, presented the operation of the market mechanism — as nobody had done before him — in a formalized form. The 'invisible hand' of the market of A. Smith, the creator of the school of Lausanne, was replaced by the 'auctioneer') who runs an auction in accord- 
ance with the tâtonnement procedure, that is in the dark. This concept was developed by the creator of the school of Lausanne in the subsequent editions of Éléments d'économie politique pure. Walras's auctioneer, or the mechanism coordinating the operation of entities on the market, makes all the markets empty. Owing to the auctioneer, there is a perfect coordination of the activities of business entities. L.M.E. Walras (1874, pp. 126 et seq.; 1896, pp. 3 et seq.) showed that thanks to the auctioneer there is a general balance and the auctioneer guarantees the optimization of transactions on all the markets. This means that the equilibrium prices set by the auctioneer empty all the markets. Business entities accept prices set by the auctioneer, and they themselves determine the quantities of goods offered for sale. It follows from the above that all frictions in the system are first reacted to by prices and the quantities adjust with delay.

\section{The renaissance of statism}

Although in the eighteenth and nineteenth centuries laissez-faire reigned supreme in the science of economics and economic policy, not all social thinkers succumbed to this trend. The position of the classics was contested by, among others, socialists and representatives of the historical direction. Ferdinand Lassalle, a German politician, social thinker and proletarian leader, advocated the strengthening of the role of the state in the economy. Lassalle (1878, pp. $1-211 ; 1889$, pp. 55-75; 1905, pp. 31-64; 1907, pp. 3-32) claimed that the state should play a decisive role in economic life. He rejected the self-limitation of the state to the role of a 'night watchman' (an expression introduced by F. Lassalle), because this institution should serve the public, be its representative, and create a climate for social solidarity. The state is thus obliged to protect and support the working class and improve its material conditions.

The forerunner of historicism, Johann Gottlieb Fichte (1917, pp. 7-98; 1996, pp. 156-161, 266 et seq.), argued that the political power should be exercised by the state controlling the economic life. Its main task was to guarantee work for all members of society and to protect property, as well as oversee industry and trade, in order to keep them in balance. The implementation of these demands required the creation of autarchy. The state was to regulate goods, set prices, and regulate relations between income groups.

The historical school was also represented by Adolph H.G. Wagner (1895, pp. 4-39), who proclaimed the need for interference by the state in economic life in order to improve the material conditions of hired workers. State functions are constantly expanding and the scope of state intervention is growing. The market mechanism does not satisfactorily meet collective needs. The state should decide on the distribution of the social product. This goal is achieved by the state through the use of a redistributive tax policy. This function becomes particularly desirable because the mechanism of free competition leads to excessive income disparities. A.H.G. Wagner (1883, pp. 17 et seq.; 1892, pp. 22 et seq.; 1904, pp. 2-9, 72) allowed the possibility of direct economic activity 
by the state, mainly to provide all citizens with access to the basic necessities. The state should undertake a business activity when the private initiative does not satisfy the needs of the citizens at all, or conducts a more or less expensive activity.

\section{The birth of modern interventionism}

As in the $18^{\text {th }}$ and $19^{\text {th }}$ centuries, the position of laissez-faire also seemed unchallenged at the beginning of the $20^{\text {th }}$ century. The defects of the liberal capitalist economy were only exposed by the Great Depression of 1929-1933. Despite the deepening and prolonged depression, rising unemployment, helpless supporters of classical orthodoxy argued that governments should not intervene in the economy. It was thought that an uninhibited and self-cleaning market would overcome depression (Galbraith, 2017, pp. 211-213). A convincing programme of repairing capitalism was presented only by the most prominent economist of the $20^{\text {th }}$ century, John Maynard Keynes. He rejected both the theses of the classics about the self-cleaning of markets and Walras's fictitious - in his opinion - auctioneer using the tâtonnement mechanism. J.M. Keynes (1936, pp. 21 et seq.) showed that the state should incur expenses, and so create additional demand, and stimulate the economy. From being the night watchman, the state was to become an important investor. Governmental recovery programmes were not expected to be a permanent element of the economic system, but only as a temporary measure. For the author of The general theory of employment, interest and money, it was obvious that the self-correcting market mechanism, constituting the basis of classical economics, had become intellectually bankrupt. In a downturn, accompanied by pessimistic moods among entrepreneurs, the state should complement the private sector, undertaking public works getting the economy moving and stimulating private investments, and should implement public investments (even if unprofitable). The state should therefore apply an expansive fiscal policy aimed at increasing global demand. Since the economy in the liberal system is permanently in a state of incomplete employment, it is necessary for the state to intervene.

Proposing a revolutionary change in the understanding of the role of the state in the economy, J.M. Keynes contributed to the institutional reconstruction of the capitalist economy, and also divided economic theorists and politicians into two feuding groups. Unfortunately, the mutual dislike, created in the middle of the $20^{\text {th }}$ century, was not compensated for by the creators of the neoclassical synthesis. They sought to agree on some of the theories and views of the proponents of classical economics and Keynesianism, which would make possible a better explanation of the modern economy that had become a mixed economy (Samuelson, 1961, pp. 37 et seq.). 


\section{The views of J.E. Stiglitz on the need for cooperation between the state and the market}

An economist who has shown that a compromise is possible between the conflicting trends in the perception of the role of the state and the market in the economy is the American representative of the new Keynesian economy: Joseph Eugene Stiglitz.

In his work entitled Economics of the public sector, J.E. Stiglitz (2004, pp. 70 et seq.) promoted the cooperation of the state and the market, which may result in their strengthening and the effective solving of social problems. He maintained that the state should intervene only in cases where there was a possibility of limiting the market failure. J.E. Stiglitz distinguished six types of market failure, which are the main causes of market inefficiency in Pareto's understanding, i.e. unreliability of competition, unreliability arising from the existence of of public goods, unreliability arising from external effects, incompleteness, i.e. no markets, unreliability arising from incomplete, i.e. imperfect information, and macroeconomic disturbances. The above types of market failures, leading to economic inefficiency as understood by Pareto, justify - according to J.E. Stiglitz - the intervention of the state in the market mechanism. But preventing market failures is often ineffective, while the objectives of public programmes are of a political nature or conceal the influence of specific interest groups. The state can also directly engage in the production of public goods, or limit itself to its financing. J.E. Stiglitz emphasizes that state intervention in the market is justified only if the activity of the state limits market failure.

According to the American economist, the Great Depression was the most vivid example of market failure. The massive unemployment and catastrophic decline in production occurring at that time were irrefutable evidence that the invisible hand of the market had failed. In the face of these dramas, the proposal of J.M. Keynes, that the state should take action to stabilize the economy and avoid recession seemed convincing. The market mechanism turned out to be unable to reduce unemployment and increase employment. The banks' bankruptcies and market slumps were equally severe, as a result of which the population lost almost all its savings, while the weaker social groups were condemned to live in poverty. As a result of the difficulties in paying off debts, the bankruptcies of farmers and the taking over of their farms by banks became a common phenomenon. The governments of some countries then applied tools to stabilize economic activity and implemented a social security system, unemployment insurance, and insurance for bank deposit holders, as well as minimum prices for agricultural produce. After the Second World War, universal education programmes were implemented to increase employment opportunities and the fight against poverty and social stratification was applied through the introduction of new social assistance programmes. These included universal access to health care, better nutrition, vocational training, and kindergartens for children from the poorest families. These activities were aimed at increas- 
ing the possibilities of economic promotion to larger social strata. After several dozen years, it turned out that only some of the activities led to the solution of thorny problems. For example, the governmental programme of medical assistance to poor people increased access to health care, but it did not eliminate the differences in life expectancy between the rich and the poor. The war against poverty ended with a complete fiasco (Stiglitz, 2004, pp. 7-9).

Although the purpose of some government programmes was - as J.E. Stiglitz admits - to improve the market, they had opposite effects. By implementing a programme to improve the housing conditions of the indigent population in the city centres, old houses were demolished and new ones were built with a higher standard. Rents for new apartments reduced access for poor people, condemning them to live in even worse conditions. This programme also contributed to the increase of homelessness. The effect of omitting the basic market rights was the reduction of the supply of houses and apartments for rent and the deterioration of the quality of housing services. In turn, large farms benefited the most from farm assistance programmes, while a large proportion of small farms was doomed to collapse. The programme of integrating children of different races in American public schools was only partially successful. Market failure - according to J.E. Stiglitz (2004, pp. 9-10) — is an important motive for the state's influence on the economy.

According to the author of the Economics of the public sector, market failures were to be limited by public programmes undertaken by the state. Unfortunately, many of them did not bring the expected results. Their ineffectiveness testified to the failure of the state. The American economist mentions four causes of state failure. He included in them: a limited amount of available information, limited control over the effects of state actions in private markets, limited control over bureaucracy, and restrictions of a political nature. J.E. Stiglitz argued that for the opponents of state influence on the economy, the above-mentioned sources of state failure constitute a sufficient argument for abandoning intervention in the economy and attempting to repair the market mechanism. However, attempts to improve the market mechanism by some governments generally failed. This means that neither the market nor the state were working perfectly, that is, reliably, emphasizes J.E. Stiglitz. If the state operates imperfectly, its intervention should be limited to only those cases where market failure is greater and the intervention proves to be effective in solving specific problems. J.E. Stiglitz (2004, pp. 10-13) rejected the position advocated by many American economists that the state should intervene in a limited way and seek to alleviate (not solve) the most pressing social and economic problems. Priority goals include the ensuring of full employment and eliminating of poverty. Private enterprises should remain the main pillars of the modern economy. Instead of putting the state and the market in opposition to each other, one should look for a level of cooperation leading to mutual reinforcement. Achieving this goal is possible under the condition of basing the state's activity on the market mechanism. 
J.E. Stiglitz in his work The roaring nineties: a new history of the world's most prosperous decade also warned against over-regulation of the economy or excessive deregulation. Its author claimed that there should be a balance between the state and the market. Both excess regulation and its deficiency may turn out to be unfavourable for the entire country. An insufficient level of state-owned investments as well as too large amounts of state expenditure may be harmful to the economy. The government can therefore stabilize the economy, but also increase fluctuation by using inadequate tools. There is a continuous dispute between supporters of limiting the role of the state to a minimum, and supporters of an active state that plays an important but limited role. The latter attribute to the state the task of correcting errors, market restrictions, and ensuring greater social justice. J.E. Stiglitz (2006, pp. 26-31) declared himself to belong to the latter camp. His position was that it was the market that mainly contributed to the success of the American economy. At the same time, he maintained that the market does not always function well and cannot solve all problems. Therefore, the state will have to play the role of an important partner. It is therefore necessary to ensure the right balance between the market and the state.

According to J.E. Stiglitz, the liberalization of the financial system also contributed to the outbreak of the crisis in 2007. This issue was developed in the publication entitled Freefall: America, free markets, and the sinking of the world economy: true measures of money, business, and life. The principles of capitalism created in the second half of the twentieth century proved to be unclear and not egalitarian. The privileged financial institutions were exempted from the obligation to comply with market discipline, resulting in the bankruptcy of unprofitable entities. Contrary to fundamental economic principles, these institutions made too risky decisions at public expense. Declarations on transparency and economic imagination, made by politicians, were accompanied by simultaneous bank manipulations and the greed of financiers. The equilibrium between the market and the state, means, and goals, individualism, and community, as well as man and nature, were disturbed. The ideology of market fundamentalism was replaced by the argument of economic support for their own enterprises, both by rich and poor countries. Therefore, necessary - according to J.E. Stiglitz (2010, pp. XV et seq.) - are changes in the political and economic system. Therefore, the author of Freefall demanded a thorough reconstruction of the financial system, adapted to the needs of people, as well as the construction of a new economic system in which new useful jobs would be created for those seeking decent employment. This new system should, above all, guarantee greater equality of assets (Stiglitz, 2010, pp. 341-342).

The problem of material disproportions J.E. Stiglitz addressed in more detail in the book The price of inequality: how today's divided society endangers our future. He emphasized that the recession of 2007-2010 aggravated income and wealth inequalities between the richest, the medium wealthy, and the poor Americans. Not only that, property inequalities increased even more than income inequalities. What is worse, in the last three decades, the income of the majority of US 
citizens dropped, while the richest per mille, that is around 16,000 families, doubled their income and assets. This is evidenced by the Gini coefficient, which in the years 1980-2009 increased from 0.4 to 0.47. Despite the prosperity of capitalism and the wealth of the richest, no new jobs were found in the private sector. Once again, the view that the more money is left with the rich, the more jobs they will create, turned out to be a myth. Once again, it turned out that the markets are defective. Also, owing to market failure, the author of The price of inequality referred with reserve to the privatization of state-owned enterprises, which in many cases was accompanied by corruption and ideological, rather than economic considerations (Stiglitz, 2015, pp. 8 et seq.). The activity of markets is not consistent with the claim of their enthusiasts. The rightness of their views was undermined by the global economic crisis which pointed to the significant instability of the markets. The market should be effective, but it is deprived of this quality. The worst manifestation of the disability and the cause of the inefficiency of the market is unemployment, i.e. the inability to find a job, which, in turn, is the main source of inequality (Stiglitz, 2015 , p. 40). Inequalities perpetuate and deepen when there is a bad legal order and when an erroneous macroeconomic policy, especially monetary policy, is adopted. At the same time, inequalities have a destructive effect on the rule of law, and generate distrust, feelings of injustice, disappointment and powerlessness, and undermine the principles of democracy. Deep inequalities cause instability and negatively affect the efficiency and productivity of the economy, i.e. they weaken the entire economy. He also said it was also a lie to say that inequalities positively affect the motivation of people to work, save, and invest. In connection with the above, it is the state - according to J.E. Stiglitz (2015, pp. 142 et seq.) - that should shape the market, mainly through the establishment of basic rules of the game, control the distribution and effectiveness of the existing and newly introduced legal solutions, and policies. The most important role in reducing inequalities lies in the state's tax policy, aimed at accelerating economic growth, and the effective control of the budget deficit. The state, through its actions, distorted the market, which led to an increase in inequality. The government's tendency to correct and balance market forces decreased as the inequalities deepened. It was the state that created the rules of the game, which only helped the rich to increase their fortunes and deprive the poor. J.E. Stiglitz (2015, pp. 170 et seq.), like most progressivists, took the position that the reduction of income and property disparities leads to increased productivity of the economy. He emphasized that he was a committed advocate of the policy of efficiency and justice. Rents which come from the poorer and moderately wealthy layers are the sources of income for the richest social strata. Also, rents contributed to the distortion of the market, which the rich benefited, while the poor lost. The creation of appropriate rules of the game, enabling the markets to fulfil their role, increase competition, and reduce exploitation, is a condition for a more efficient economy and fairer society, stated Stiglitz (2015, p. 429). 


\section{Conclusion}

The considerations on the role of the state and the market in the economy have - as shown in the above analysis - a long and rich history of about 2,400 years. During this period, dozens of concepts have been created. Their creators justified them with convincing arguments, but in many cases they did not fit in with the surrounding reality or turned out to be ineffective in solving major socio-economic problems.

Plato and St. Thomas More argued that an omnipotent state should replace the market and regulate economic processes. Mercantilists advocated state control of the economy. Still in the nineteenth and twentieth centuries, socialists and representatives of historicism pointed to the need to strengthen the role of the state in the economy. In the $18^{\text {th }}$ century, laissez-faire had become the dominant trend. B. Mandeville, and then V.J.C.M. de Gournay, and R. Cantillon, postulated that the state should not interfere with economic matters, because the unhampered activity of the market ensures equilibrium. Their views were developed by A. Smith, who showed that the market mechanism, or the 'invisible hand' of the market, coordinates the activities of all individuals and ensures effective satisfaction of their needs. This position was supplemented by L.M.E. Walras proving that thanks to the auctioneer all markets become empty. After the outbreak of the Great Depression, it turned out that the free market is helpless in the face of a deep depression. A remedy for the system was by introduced by J.M. Keynes. He acknowledged that an active state that will stimulate the economy during a downturn is an effective solution. The emergence of Keynesianism deepened the division between the two feuding groups of economic theorists and politicians.

A completely new proposal for the relationship between the state and the market was presented by J.E. Stiglitz, who advocated the cooperation of the state and the market, in order to effectively solve social problems, as well as to work out a balance between the state and the market. He holds that both overregulation of the economy and excessive deregulation are dangerous. The effect of deregulation is not only the periodic breakdown in production growth, but also income and property inequalities that negatively affect people's behaviour. J.E. Stiglitz thus proved that the state and the market are not mutually exclusive mechanisms, and that the symbiosis of the state with the market is possible. The representatives of this trend showed that neither the market nor the state itself would ensure economic efficiency in modern economies. It is a mistake to set them in opposition to each other. It follows from the above that the idea of cooperation between the state and the market should take a permanent place in economic thought and practice. Instead of discussing the 'state or market' dilemma, one should consider how much state and how much market there should be. This means that the proposals of J.E. Stiglitz rendered obsolete the dispute on the mechanism of resource allocation between supporters of statism (interventionism) and supporters of liberalism. 


\section{References}

Cantillon, R. (1979). Essai de la nature du commerce en général. Texte manuscrit de la Bibliothèque de Rouen. Avec le texte de l'édition oryginale de 1755 et une étude bibliographique par T. Tsuda. Tokyo: Kinokuniya Book-Store.

Child, J. (1751). A new discourse of trade. Glasgow: Robert and Andrew Foulis.

Dach, Z. (Ed.). (2008). Państwo a rynek we wspótczesnej gospodarce: wybrane problemy. Kraków: PTE.

Fichte, J.G. (1917). Der geschloßene Handelsstaat. Ein philosophischer Entwurf als Probe einer künstig zu liefernden Politik. Leipzig: Im Insel-Verlag.

Fichte, J.G. (1996). Teoria wiedzy: wybór pism. Vol. 1. Warszawa: PWN.

Galbraith, J.K. (2017). Economics in perspective: a critical history. Princeton: Princeton University Press. doi:10.2307/j.cttlvwmhch.

Hales, J. (1958). Rozprawa o wspólnym pożytku królestwa Anglii. In E. Taylor \& S. Zaleski (Eds.), Merkantylizm i początki szkoty klasycznej: wybór pism ekonomicznych XVI i XVII wieku. Warszawa: PWN.

Jarmołowicz, W. (Ed.). (2012). Liberalizm ekonomiczny w dobie transformacji, integracji i globalizacji. Poznań: UE w Poznaniu.

Keynes, J.M. (1936). The general theory of employment, interest and money. London: Macmillan.

Lassalle, F. (1878). Kapitat i praca, czyli pan Bastiat-Szulce z Delicza, Julian ekonomiczny. Lwów: Antonii Mańkowski.

Lassalle, F. (1889). Wybór pism. Paryż: Librairie Ghio.

Lassalle, F. (1905). Nauka a robotnicy: mowa obrończa wypowiedziana przed Berlinskim Sądem Karnym. Warszawa: Bibljoteka Naukowa.

Lassalle, F. (1907). Program robotników: wykład o szczególnym związku obecnego okresu dziejowego z idea klasy robotniczej. Warszawa: Biblioteka Ludowa.

Mandeville, B. (1988). The fable of the bees or private vices, public benefits. Indianapolis: Liberty Fund.

Misselden, E. (1622). Free trade, or the meanes to make trade florish. London: John Legatt.

Misselden, E. (1623). The circle of commerce, or the balance of trade. London: John Dawson.

Montchrétien, A. (1970). Traicté de l'œeconomie politique dédié en 1615 au roy et à la reyne mère du roy. Genève: Slatkine Reprints.

More, T. (1964). Utopia. New Haven-London: Yale University Press.

Mun, T. (1856). A discourse of trade, from England unto the East Indies. In J.R. McCulloch (Ed.), A select collection of early English tracts on commerce from the originals of Mun, Roberts, North, and others, with a preface and index. London: Political Economy Club.

Owsiak, S. (Ed.). (2017). Państwo a gospodarka. Warszawa: PTE. 
Petty, W. (1899a). A treatise of taxes and contributions, In: Ch.H. Hull (Ed.), The economic writings of sir William Petty, together with the observations upon the bills of mortality, more probably by captain John Graunt. Vol. 1. Cambridge: Cambridge University Press.

Petty, W. (1899b). Political arithmetick. In: Ch.H. Hull (Ed.), The economic writings of sir William Petty, together with the observations upon the bills of mortality, more probably by captain John Graunt. Vol. 1. Cambridge: Cambridge University Press.

Petty, W. (1899c). Verbum sapienti. Ch.H. Hull (Ed.), The economic writings of sir William Petty, together with the observations upon the bills of mortality, more probably by captain John Graunt. Vol. 1. Cambridge: Cambridge University Press.

Plato. (1992). The republic. London: Everyman's Library.

Quesnay, F. (1928). Prawo przyrodzone. In F. Quesnay, Pisma wybrane. Warszawa: Gebethner i Wolff.

Samuelson, P.A. (1961). Economics: an introductory analysis. New York-Toronto-London: McGraw-Hill.

Serra, A. (1958). Krótki traktat o przyczynach, które mogą sprowadzić obfitość złota i srebra w krajach nieposiadających kopalni. In E. Taylor \& S. Zaleski (Eds.), Merkantylizm i początki szkoty klasycznej: wybór pism ekonomicznych XVI i XVII wieku. Warszawa: PWN.

Smith, A. (1863). An inquiry into the nature and causes of the wealth of nations. Edinburgh: Adam and Charles Black.

Smith, A. (2004). The theory of moral sentiments. Cambridge: Cambridge University Press.

Stiglitz, J.E. (2004). Ekonomia sektora publicznego. Warszawa: PWN.

Stiglitz, J.E. (2006). Szalone lata dziewięćdziesiąte: nowa historia najświetniejszej dekady $w$ dziejach świata. Warszawa: PWN.

Stiglitz, J.E. (2010). Freefall: jazda bez trzymanki: Ameryka, wolne rynki i tonięcie gospodarki światowej. Warszawa: PTE.

Stiglitz, J.E. (2015). Cena nierówności: w jaki sposób dzisiejsze podziaty społeczne zagrażają naszej przysztości. Warszawa: Krytyka Polityczna.

Turgot, A.R.J. (1844). Éloge de Gournay. In Oeuvres de Turgot. Paris: Guillaumin.

Wagner, A. (1883). Finanzwissenschaft. 1. Theil. Leipzig-Heidelberg: C.F. Winter'sche Verlagshandlung.

Wagner, A. (1892). Grundlegung der politischen Oekonomie. 1. Theil. Leipzig: C.F. Winter'sche Verlagshandlung.

Wagner, A. (1895). Die akademische Nationalökonomie und der Socialismus. Berlin: Druck von Julius Becker.

Wagner, A. (1904). Die finanzielle Mitbeteiligung der Gemeinden an kulturellen Staatseinrichtungen und die Entwickelung der Gemeindeeinnahmen. Mit besonderem Bezug auf preussische Verhältnisse. Jena: von Gustav Fischer.

Walras, L. (1874). Éléments d'économie politique pure, ou théorie de la richesse sociale. Lausane-Paris-Bale: Imprimerie L. Corbaz-Guillaumin-H. Georg. 
Walras, L. (1896). Études d'économie sociale : théorie de la répartition de la richesse sociale. Lausanne-Paris: F. Rouge Libraire-Éditeur-R. Pichon Imprimeur-Éditeur.

Walras, L. (1926). Éléments d'économie politique pure, ou théorie de la richesse sociale. Paris-Lausane: R. Pichon et R. Durand-Auzias-F. Rouge Libraire-Éditeur. Zagórski, J. (1963). Ekonomia Franciszka Quesnaya. Warszawa: PWN.

\section{Acknowledgements}

Author contributions: author has given an approval to the final version of the article.

Funding: this research was fully funded by the Nicolaus Copernicus University in Torun.

Note: the results of this study were presented at 8th International Scientific Conference: Contemporary Economic Problems 'Social-economic problems in the era of globalization: theory and practice' (May, 22, 2019, Torun, Poland). 
